\title{
Justiça Orfanológica no final do século XIX: o Juízo dos Órfãos de Porto Alegre.
}

\section{Orphanological Justice in the late nineteenth century: the Court of Orphans.}

José Carlos da Silva Cardozo*

Resumo: O Juízo dos Órfãos foi uma importante instituição que, desde o período colonial brasileiro, zelou pelos interesses dos menores de idade que a ela eram apresentados. Esta instituição galgou importância dentro do Judiciário, outorgando maior prestígio e estabilidade aos operadores do direito da instituição. Este texto analisa as transformações legais pela qual a instituição passou, desvela as funções dos agentes desta instituição e evidencia a gradual importância que a função de Juiz de Órfãos vai recebendo do Estado.

Palavras-Chave: Juízo dos Órfãos. Porto Alegre. Rio Grande do Sul. Século XIX.

Abstract: The Court of Orphans was an important institution that, since the Brazilian colonial period, took care of the interests of minors who were presented to it. This institution gained importance within the Judiciary, granting greater prestige and stability to the operators of the institution's law. This text analyzes the transformations legal changes that the institution has undergone, reveals the functions of the agents of this institution and shows the gradual importance that the function of Judge of Orphans is receiving from the State.

Keywords: Court of Orphans. Porto Alegre. Rio Grande do Sul. XIX century.

Porto Alegre, onze de janeiro de 1870, terça-feira. Nesse dia, foi dada a entrada ao processo de Tutela número 922 no Juízo dos Órfãos da $2^{\text {a }}$ Vara de Porto Alegre. Nessa ação, Francisco Coelho Barreto informava que, em dezembro do ano anterior, havia falecido Margarida Candida da Silva Bueno, viúva, mãe de quatro filhos

\footnotetext{
* Historiador (UNISINOS) e Sociólogo (UFRGS). Doutor e Pós-Doutor em História Latino Americana. Professor na Universidade Federal do Rio Grande (FURG - Campus Santa Vitória do Palmar) e na Rede Adventista de Ensino (USB). Editor da Revista Brasileira de História \& Ciências Sociais.
} 


\section{Revista Brasileira de História \& Ciências Sociais - RBHCS}

Vol. $9 \mathrm{~N}^{\mathrm{O}}$ 18, Julho - Dezembro de 2017

legítimos: Eduardo, Pedro, Ermelinda e Saturninaํㅗ os quais estavam desamparados, sem nenhum outro familiar que pudesse cuidar deles, pois os demais nem mesmo teriam podido dar à falecida uma "sepultura”.

O senhor Francisco Barreto acrescentava que os dois últimos estavam em sua companhia e que a falecida senhora havia deixado como únicos bens um "mulatinho" de nome Silvino, com "idade de 16 anos pouco mais ou menos" e "alguns bens móveis de arranjo de casa". Sendo assim, pedia que a tutela das duas últimas crianças, que estavam em sua casa, fosse entregue a ele, bem como seus “bens”, para evitar “arguições futuras”, ou seja, queria regularizar a guarda dos menores, evitando, assim, problemas.

Ao receber os autos em suas mãos, no mesmo dia da abertura, o Juiz do caso, Dr. Antônio Correa de Oliveira, Primeiro Suplente em exercício no Juízo dos Órfãos de Porto Alegre, deferiu o pedido de tutoria em favor do suplicante Francisco Coelho Barreto.

Contudo, quase dois meses após a entrega de Ermelinda e Saturnina, numa quarta-feira, dia nove de março, o processo voltou às mãos do Juiz com uma triste notícia: o tutor havia falecido.

José da Silva Mello Guimarães, parente de Francisco Barreto e das meninas, apresentou a notícia da "repentina" morte do tutor com um pedido ao Juiz - ser nomeado tutor das menores Ermelinda Soulai de Jansem ${ }^{3}$ e Saturnina da Silva Bueno. O pedido foi deferido somente quatro meses depois, na quinta-feira, quatorze de julho daquele ano. Finalmente, Ermelinda e Saturnina teriam seu destino definido em relação à família que receberia a sua guarda.

Ao findar o processo número 922, relativo ao ano de 1870, poderíamos nos indagar quanto aos outros dois irmãos das meninas, Eduardo e Pedro. Eles não haviam sido arrolados nem nesse, nem em outros autos judiciais com registro nesse período: para onde teriam ido? Quanto ao menor Silvino, cujo nome havia sido transcrito numa linha de papel, para, logo em seguida, se "perder" na História,

\footnotetext{
${ }^{1}$ RIO GRANDE DO SUL. Juízo Districtal da Vara de Orphãos de Porto Alegre. $2^{\text {a }}$ Vara. Tutela. Proc. $\mathrm{n}^{0} 922$ de 1870. [manuscrito]. Porto Alegre, 1870. Localização: APERS.

2 Esclarecemos que os excertos extraídos dos processos encontram-se escritos entre aspas e em itálico.

$3 \mathrm{Na}$ carta de alforria do Silvino aparece Ermelinda Adelaide Jansen. Silvino era de cor parda e tinha como senhora, Ermelinda Adelaide Jansen. O documento foi lavrado entre 05/01/1877 e 18/01/1877. A carta foi concedida em retribuição aos bons serviços prestados. $O$ escravo foi recebido de herança da falecida mãe da senhora, Margarida Cândida da Silva Bueno. ( 1 o Tabelionato de Porto Alegre Livro 24 Notarial de Transmissões, página: 076v. Arquivo Público do Estado do Rio Grande do Sul APERS).
} 


\section{Revista Brasileira de História \& Ciências Sociais - RBHCS}

Vol. $9 \mathrm{~N}^{\mathrm{O}}$ 18, Julho - Dezembro de 2017

permanece a dúvida: o que teria acontecido com ele? Por que, num momento, o Juiz do caso agira de forma rápida, tomando a decisão em menos de um dia, para logo em seguida demorar mais de quatro meses para dar seu veredicto sobre o mesmo processo?

Mas, para além dessas questões, chama-nos a atenção a instituição a qual julgou a ação judicial: Juízo dos Órfãos de Porto Alegre. Quem era e qual sua função dentro do cenário jurídico de então? Ser Juiz de Órfãos era um cargo de prestígio dentro da sociedade brasileira?

\section{O Juízo dos Órfãos}

O século XIX seria importante para a tomada do reconhecimento do Juízo dos Órfãos como instituição fundamental na dinâmica da sociedade brasileira e como uma das formas de acesso às carreiras de prestígio tanto na área jurídica quanto na política regional ou nacional.

O Juízo dos Órfãos, como grande parte das instituições do Brasil Colônia e Império, é de origem portuguesa, tendo surgido com as Ordenações Manuelinas, em 1512. A criação desse Juízo deveu-se à necessidade de definir normas que regulamentassem a proteção dos menores de 25 anos de idade4, no que competia à administração própria e de seus bens. O cuidado e a administração dos órfãos, por parte de um adulto legalmente constituído, eram necessários em vista dos processos de separação de bens (partilha) ou mesmo de herança em virtude de falecimento do pai do menor. Numa contingência desse tipo, o adulto ficaria responsável por representar os interesses do menor nesse processo que, em certas circunstâncias, poderia se transformar numa ação que desembocasse em litígio5. A necessidade de um adulto como responsável por um menor também poderia vir pela orfandade completa em que este menor poderia encontrar-se. Assim, nesse primeiro momento,

\footnotetext{
4 É necessário esclarecer que, somente depois da Independência do Brasil, com a resolução de 31 de outubro de 1831, é que a idade de 21 anos foi definida como idade limite da menoridade de um filho, ou seja, idade limite do pátrio poder sobre o mesmo e só em 1990, com o Estatuto da Criança e do Adolescente, é que a idade de 18 anos seria fixada como limite da menoridade no Brasil. Ver: RIO GRANDE DO SUL. Ministério Público. Centro de Apoio Operacional de Infância e da Juventude. Estatuto da criança e do adolescente e legislação pertinente. Porto Alegre: ProcuradoriaGeral de Justiça, 2007.

5 Litígio, segundo o dicionário jurídico, é a "demanda, disputa; pendência, contenda... O litígio somente terá início quando a parte contesta o pedido do autor" Ver: SANTOS, Washington dos. Dicionário jurídico brasileiro. Belo Horizonte/MG: Del Rey, 2001, p. 153.
} 


\section{Revista Brasileira de História \& Ciências Sociais - RBHCS}

Vol. $9 \mathrm{~N}^{\mathrm{O}}$ 18, Julho - Dezembro de 2017

o Juízo dos Órfãos deteve suas atenções naqueles menores de idade que possuíssem bens ou fossem descendentes de família de posse e/ou de prestígio social.

O Juizado de Órfãos, como também era chamado, foi igualmente instalado na colônia portuguesa na América e, até o século XVIII, o cargo de Juiz de Órfãos era exercido pelo Juiz Ordinário6 ${ }^{6}$, indivíduo que não era, necessariamente, bacharel em Direito. Porém, com o aumento da população na colônia, foi regulamentado, em maio de 1731, o cargo de Juiz de Órfãos no Brasil. Em Porto Alegre, esse cargo foi criado em 26 de janeiro de 1806, teve sua reorganização administrativa em 1927, com o Código de Menores, e sua completa reformulação das atividades em 1933, ano em que foi criado o Juizado de Menores pela intendência municipal.

Ao longo dos anos, essa instituição judiciária foi ampliando sua ação, direcionando sua atenção também para os menores não pertencentes às famílias das elites. No caso do Brasil, especialmente a partir da formulação das leis "antiescravistas". No ano de 1871, a Lei do Ventre Livre instituiu que as crianças nascidas de ventre escravo, a partir daquele ano, seriam consideradas "ingênuas" e não mais escravas, ficando, assim, "livres" do jugo senhoril e, em 1888, pela promulgação da Abolição, houve a libertação por completo dos escravos de seus antigos senhores. Com essas e outras medidas que visavam à lenta liberdade do cativeiro, houve a necessidade do contingente de escravos e ex-escravos ser direcionado para o trabalho assalariado7.

Dessa forma, o Juízo de Órfãos era o tribunal, ou foro, em que se tratava e decidia tudo o que dizia respeito a um menor de idade, ou pessoas incapacitadas, como os pródigos (pessoas que gastam seu capital ou destroem seus bens (Ord. Fil. liv. $4^{\text {a }}$, tit. $103 \S 6$ ), os furiosos (pessoas com as faculdades mentais debilitadas - Ord. Fil. liv. $4^{\mathrm{a}}$, tit. 103), os doentes graves (pessoas impossibilitadas de administrar seus bens) e os indígenas (Ord. Fil. liv. $1^{\circ}$, tit. 88). Pela forma da lei vigente, essas pessoas, embora atingissem a maioridade legal, necessitavam de um adulto legalmente

\footnotetext{
${ }^{6}$ Esse juiz era leigo e eleito anualmente pelos "homens bons" da jurisdição. O cargo foi criado em 1521. 7 Sobre o tema, recomendamos ver: GEBARA, Ademir. O mercado de trabalho livre no Brasil. São Paulo: Editora Brasiliense, 1986. CHALHOUB, Sidney. Machado de Assis: historiador. São Paulo: Companhia das letras, 2007. MOREIRA, Paulo Roberto Staudt. Entre o deboche e a rapina: os cenários sociais da criminalidade popular em Porto Alegre. Porto Alegre: Armazém Digital, 2009. CARDOZO, José Carlos da Silva. "Como se fosse meu filho"? As crianças e suas famílias no Juízo dos Órfãos de Porto Alegre (1860-1899). Tese (Doutorado em História). Universidade do Vale do Rio dos Sinos, 2015.
} 


\section{Revista Brasileira de História \& Ciências Sociais - RBHCS}

Vol. $9 \mathrm{~N}^{\mathrm{O}}$ 18, Julho - Dezembro de 2017

constituído por esse Juízo (o curador) como seu representante e responsável (Ord. Fil. liv. $4^{\text {a }}$, tit. $\left.104 \S 6\right)$.

\section{A regulação das Leis I: as Ordenações.}

A legalidade dessas ações residia nas Ordenações portuguesas (Afonsinas, Manuelinas e Filipinas), que representaram um esforço para congregar e sistematizar o corpo normativo do Império Português. Conhecidas como "Ordenações do Reino", eram um conjunto de cinco livros (cada uma manteve a mesma divisão), que reuniam vários aspectos do direito luso, do qual não haveria positividade/legalidade fora dos códigos.

Segundo os professores de direito Rui Marcos, Carlos Mathias e Ibsen Noronha (2014), as Ordenações Afonsinas foram uma resposta ao clamor do povo pela necessidade de compilação das leis portuguesas para "evitar a incerteza" e promover a "boa administração da justiça". Acredita-se que o projeto e a publicação das Ordenações Afonsinas tenham sido concluídos entre os anos de 1446 e 1447. Esse trabalho teria sido iniciado durante o reinado de D. João I, e sua elaboração teria se estendido pela administração do Infante D. Pedro, regente do trono na menoridade de D. Afonso V; contudo, inúmeras foram as dificuldades para a aplicação e difusão dessas normativas, uma vez que, além de a cópia ser manuscrita - e, portanto, não estar livre de erros -, o preparo desigual entre os magistrados da capital do reino e o dos meios rurais tornava difícil a aplicação das normativas.

Não demorou muito tempo para que houvesse a necessidade de atualização das Ordenações, trabalho realizado no reinado de D. Manuel I, que reuniu seus mais proeminentes juristas para a tarefa: Rui Boto, Chanceler-Mor, Rui da Grã, Desembargador do Paço, e João Contrim, Corregedor do Cível (MARCOS; MATHIAS; NORONHA, 2014). Esse conjunto de especialistas foi encarregado de modificar, suprimir e acrescentar melhorias no código, que permitiram sua readequação. Com o advento da imprensa em Portugal, ocorreu sua disseminação pelos vários cantos do Império, tendo chegado, inclusive, ao Brasil. Em termos de comparação, não houve uma grande mudança entre uma e outra, alterou-se o estilo da redação de “compilatório" para "decretório". Mas a substancial mudança ocorreu na lei relativa 


\section{Revista Brasileira de História \& Ciências Sociais - RBHCS}

Vol. $9 \mathrm{~N}^{\circ}$ 18, Julho - Dezembro de 2017

aos mouros e judeus, que, até então, os obrigava à conversão ao catolicismo ou à expulsão do Império.

No ano de 1569, veio à luz um conjunto de leis conhecida como Leis Extravagantes de Duarte Nunes do Lião. A necessidade da reunião dessas leis deve-se à descoberta e expansão de novos territórios que demandavam uma nova normatização, fato que acabou por, digamos, "desordenar" as Ordenações Manuelinas, na medida em que várias leis modificaram ou ampliaram a legislação. Dessa forma, as Leis Extravagantes foram uma forma de reunir normativas avulsas numa espécie de "apêndice” às Ordenações.

As Ordenações somente voltariam a vigorar a partir do período conhecido como União Ibérica (1580-1640), quando o rei espanhol Felipe II, pelo vínculo parental, reivindicou o trono português após o falecimento do rei D. Henrique, que, por sua condição de cardeal, não havia deixado herdeiros ao trono. Assim, surgiam as Ordenações Filipinas, que teriam um caráter mais de atualização do que de inovação (MARCOS; MATHIAS; NORONHA, 2014), pois nasceram com o objetivo de promover a retirada das leis já revogadas ou ultrapassadas e a inclusão das novas normas que estavam pulverizadas nas várias leis extravagantes.

A base do direito brasileiro, por muito tempo, teve como cerne as Ordenações Filipinas, que entraram em vigência por meio da Lei de 19 de janeiro de 1603, em Portugal, e mantiveram-se, mesmo com a Independência do Brasil, em 1822. O próprio D. Pedro I, como regente e, depois, como imperador constitucional, manteve as Ordenações Filipinas aplicáveis ao Brasil, enquanto não fosse promulgado o Código Civil, prometido para o ano seguinte ao da Independência; contudo, somente, quase um século depois, em 1916, as Ordenações Filipinas foram suprimidas no Brasil, com a introdução do Código Civil ${ }^{8}$. Em Portugal, estas tiveram sua existência ceifada antes, em 1867, com o Código Civil português. A inovação em relação ao precedente código foi a introdução do contrato de sociedade e companhia e sobre o direito de nacionalidade (MARCOS; MATHIAS; NORONHA, 2014); o Livro V das Ordenações Filipinas manteve a truculência das condenações ${ }^{9}$, tendo sido substituído pelo Código Penal brasileiro, em 1850.

\footnotetext{
8 À exceção dos menores de idade, que somente receberiam uma legislação própria em 1927. Até essa data, as Ordenações pautaram a base das decisões dos juízes. Sobre o tema, recomendamos ver: CARDOZO, José Carlos da Silva. Enredos tutelares: o Juízo dos Órfãos e a atenção à criança e à família porto-alegrense no início do século XX. São Leopoldo/RS: Oikos; Editora UNISINOS, 2013.

9 Para uma análise sobre o livro V, recomendamos ver: LARA, Silvia (Org.). Ordenações Filipinas: Livro V. São Paulo: Companhia das Letras, 1999.
} 


\section{A regulação das Leis II: o Juízo dos Órfãos.}

Como já mencionamos, o cargo de Juiz de Órfãos surgiu com as Ordenações Manuelinas, mas podemos encontrar menções as suas funções já nas Ordenações Afonsinas, que recomendavam certos cuidados em relação aos menores de idade:

porque os bens dos órfãos andam em má arrecadação, trabalhem-se os juízes, a que dele é dado cargo especial, ou os ordinários, onde juízes especiais deste não houver, de saberem logo todos os menores, e órfãos que há na cidade, e termos; e aos que tutores não são dados, que lhes deem logo; e façam fazer partições de seus bens, e os entregar aos tutores por conta, e recado, e inventário feito por escrivão de seu oficio; e para não se poderem seus bens alhear, façam logo um livro, e ponham-se nos armários na arca da cidade, ou vila, em que escrevam o tutor que é dado ao menor, e quando é treledado [sic], o inventário de todos os bens, que o menor acontecem [sic] (Ord. Fil. liv. 1, tit. 26, §33).

Dessa forma, já no século XV, havia a preocupação do Estado em zelar pelos menores de idade, que poderiam vir a ser lesados no desenrolar dos processos de partilhas de bens. Lembramos que essa preocupação não era estendida a todos os menores de idade, mas, sim, àqueles que pertenciam a grupos mais bem situados na sociedade lusa (possuidores de bens a receber); contudo, foi uma das primeiras vezes em que o Estado começou a dar atenção para a parcela da população que ainda não havia atingido a idade adulta, revestindo-a de direitos (ou garantindo-os) por meio de um juiz.

Quando da chegada dos portugueses à América, as Ordenações Afonsinas eram a norma vigente; contudo, devido ao fato de serem manuscritas (somente as ordenações seguintes seriam impressas) e não terem alcançado a divulgação necessária, não tiveram grande impacto no "novo mundo", uma vez que a primeira capitania criada havia sido São Vicente, em 1532, ano em que já haviam entrado em vigor as Ordenações Manuelinas.

Segundo Maria Machado (2010), que investigou os órfãos e enjeitados na cidade do Porto/Portugal, entre os anos de 1500 e 1580, na maioria das localidades portuguesas, as funções de Juiz de Órfãos eram realizadas pelo Juiz Ordinário ou 


\section{Revista Brasileira de História \& Ciências Sociais - RBHCS}

Vol. $9 \mathrm{~N}^{\mathrm{O}}$ 18, Julho - Dezembro de 2017

pelos Ouvidores; depois, começaram a aparecer juízes nomeados pelos "senhores de terras” ou pela Coroa, mas, no reinado de D. João I (1357-1433), algumas localidades receberam Juízes de Fora específicos para a função. Entretanto, segundo a mesma historiadora, D. João I almejou terminar com os Juízes e Escrivães de Órfãos, determinando que os Juízes Ordinários acumulassem a função. Interessante verificar que esta medida não alcançou êxito, pois, nas palavras de Maria Machado, "o cargo era demasiado apetecível e devia ser muito solicitado" (MACHADO, 2010, p. 40).

No século XVI, o número de Juízes de Órfãos no Império luso aumentou, tendo havido a padronização dos procedimentos assim como "a perda de competência dos Juízes Ordinários e, portanto, das Câmaras, nesta matéria" (MACHADO, 2010, p. 41). As Câmaras, de forma geral, não acolhiam a existência de Juiz de Órfãos, para não “perderem jurisdição" sobre os assuntos relacionados aos órfãos da localidade: um exemplo disso foi o ocorrido nas Cortes do século XV. Ali houve a tentativa de fazer que o cargo fosse escolhido pelos Concelhos, com mandatos trienais, para que, assim, as Câmaras continuassem a "exercer algum controle sobre os eleitos, estes são recrutados na elite local e elas dispõem de um cargo bastante atractivo para 'alimentar' as suas clientelas” (MACHADO, 2010, p. 41).

Na década de trinta do século XVI, esses magistrados passaram a ganhar ainda mais poder e importância devido à ordem real de recolherem dinheiro e outros bens de órfãos para um cofre específico (que era entregue a um depositário), de onde esses valores somente poderiam ser retirados com autorização do Juiz de Órfãos. Com o passar do tempo, houve certa "profissionalização" do cargo de Juiz de Órfãos: nas cidades mais destacadas do Império luso, este acabou tornando-se magistrado de carreira (cargo eletivo ou vitalício), que teria sob sua responsabilidade um número cada vez maior de pessoas. Tal fato acarretaria o aumento de suas atribuições como também demandaria um número maios de funcionários para atender às demandas, que poderiam ser julgadas na sua residência ou em espaços públicos, como os Paços do Concelho (MACHADO, 2010).

Entretanto, o Juízo dos Órfãos viria a alcançar toda a sua pujança transformando-se verdadeiramente numa "instituição" por meio das Ordenações Filipinas, conceito que, segundo António Manuel Hespanha, é

[...] uma ideia de empreendimento que se realiza e dura juridicamente no meio social, para realização dessa ideia organiza-se um poder que lhe procura órgãos próprios, por outro lado, entre os 
membros do grupo social interessado na realização da ideia produzem-se manifestações de comunhão dirigidas pelos órgãos e reguladas por regras de processo (HESPANHA, 1982, p. 14).

A compreensão de António Manuel Hespanha (1982) aproxima-se da ideia de Pierre Bourdieu (BOURDIEU, 2014) sobre o Estado, segundo a qual, uma das consequências da sua existência é a imposição do princípio de "visão" sobre a realidade. Em outras palavras, o Estado é o formador da verdade sobre a realidade, pois este é o construtor primordial de instrumentos da realidade social e de concepções universais, produtor de um “código comum”, que está em relação com a estrutura do Estado e, consequentemente, com aqueles que o dominam. Dessa forma, cria-se a necessidade para que se estabeleça a criação e a organização de uma resposta a essa necessidade e para que, nessa réplica, haja o desenvolvimento de mecanismos ligados ao Estado e aos grupos dirigentes para a manutenção da dominação sobre os indivíduos. Assim, o Estado procura romper com uma perspectiva extremamente arraigada nas sociedades de Antigo Regime, a saber, a governabilidade (ou o poder) mais assentada nas mãos dos homens do que nas instituições e, ao mesmo tempo, a imposição de seus desígnios sobre a população.

À medida que os Juízes de Órfãos iam adquirindo reconhecimento e prestígio pelas funções desempenhadas no Império luso e, posteriormente, no Brasil independente, passava-se a exigir destes o diploma de bacharel em direito, bem como o aumento do número de funcionários para auxiliar seu trabalho (que variava, dependendo da área abarcada e do número de habitantes na localidade).

\section{Curadores Gerais, Escrivães e Tesoureiros: os "assistentes" do Juiz de Órfãos.}

A instituição Juízo dos Órfãos era formada, basicamente, por um Juiz, um Curador Geral, um Escrivão, um Tesoureiro e um Porteiro dos Órfãos. Funções essências na instituição e que detinham considerável poder e abriam possibilidades econômicas e sociais para além das tarefas desempenhadas.

O Curador Geral de Órfãos seria futuramente conhecido como o "Promotor Público dos Órfãos”, cuja função seria a de zelar pelos interesses dos menores nos 


\section{Revista Brasileira de História \& Ciências Sociais - RBHCS}

Vol. $9 \mathrm{~N}^{\circ}$ 18, Julho - Dezembro de 2017

trâmites que corressem pelo Juízo dos Órfãos. O Promotor Público é uma figura jurídica que existe desde os tempos coloniais no Brasil, surgindo com as Ordenações Manuelinas, em 1521, e tendo sido mantida pelas Ordenações Filipinas, em 1603. A Constituição brasileira de 1824 não fazia menção ao Ministério Público ou ao cargo, mas reportava que, nos juízos criminais, a acusação caberia ao Procurador da Coroa e Soberania Nacional (exceto se a acusação não pertencesse à Câmara dos deputados); já no ano de 1828 , a Lei de 18 de setembro de $1828^{10}$, que definia as competências do Supremo Tribunal de Justiça, estabelecia o cargo de Promotor de Justiça em cada um dos Tribunais de Relação do Império (Bahia, Rio de Janeiro, Maranhão e Pernambuco).

A sistematização das atividades do Ministério Público seria definida no ano de 1832, com o Código do Processo Criminal11. O referido código, na Secção III, do artigo 36 ao 38, delimita as funções desse órgão a defensoria da sociedade. Nesses artigos, foi exposto que todos os cidadãos que teriam condições de desempenhar a função de jurado $^{12}$ poderiam ocupar o cargo, mas seriam privilegiados aqueles que fossem formados em Direito. Dessa forma, também seria possível que a função fosse cumprida por leigos, uma vez que era muito recente a implantação dos cursos de Direito no Brasil, o que se deu em 1827.

É significativo mencionar a presença da determinação da condição definidora da aptidão a ser jurado, pois, no Brasil da época, menos de $2 \%$ eram aqueles que estavam habilitados a desempenhar tal função, ou seja, tratava-se de mais um cargo destinado aos grupos da elite imperial que dominavam a política e a economia das localidades. Com o passar do tempo, e a partir do aumento do número de egressos dos cursos de Direito, passaria a ser exigido o diploma de bacharel em Direito.

Ainda, segundo o mesmo Código, os promotores seriam nomeados pelo Governo na Corte e pelos Presidentes de Província, a partir de uma lista com três nomes indicados pelas Câmaras Municipais, para um período de três anos. Tal

\footnotetext{
${ }^{10}$ BRASIL. Crêa o Supremo Tribunal de Justiça e declara suas attribuições. Lei de 18 de setembro de 1828. Disponível em: <http://www2.camara.leg.br/legin/fed/lei sn/1824-1899/lei38214-18-setembro-1828-566202-publicacaooriginal-89822-pl.html> . Acesso em: 01/06/2017.

${ }^{11}$ BRASIL. Código do Processo Criminal de Primeira Instância. Lei de 29 de novembro de 1832. Disponível em: < http://www.planalto.gov.br/ccivil_03/Leis/LIM/LIM-29-11-1832.htm>. Acesso em: 01/06/2017.

12 Os quais tinham a pré-condição de serem eleitores e, consequentemente, ser do sexo masculino, maior de 21 anos, possuir renda mínima, não ter participação em ordens religiosas e não realizar trabalhos considerados de servos ou escravos.
} 


\section{Revista Brasileira de História \& Ciências Sociais - RBHCS}

Vol. $9 \mathrm{~N}^{\mathrm{O}} 18$, Julho - Dezembro de 2017

situação, contudo, mudaria com a Reforma do Código do Processo Criminal13, de 1841. O capítulo III, nos artigos 22 e 23, colocava fim à participação da Câmara Municipal na indicação; a partir de então, esta passaria a ser considerada atribuição exclusiva do Imperador ou dos Presidentes de Província, e os promotores públicos teriam direito a receber um salário regular pela função:

Os Promotores vencerão o ordenado, que lhes fór arbitrado, o qual, na Côrte, será de um conto e duzentos mil réis por anno, além de mil e seiscentos por cada offerecimento de libello, tres mil e duzentos réis por cada sustentação no Jury, e dous mil quatrocentos réis por arrazoados escriptos ${ }^{14}$.

O desempenho na função, por sua vez, também não teria mais um período definido para sua duração; contudo, o promotor poderia ser destituído da função ad nutum, ou seja, assim como sua nomeação era prerrogativa livre do Imperador ou do Presidente da Província, sua exoneração também o era.

Com a Lei 2.048 , de 28 de setembro de $1871^{15}$, a popularmente conhecida "Lei Rio Branco" ou "Lei do Ventre Livre”, o Promotor de Justiça ia também desempenhar funções ligadas à proteção daqueles que não tinham condições de se representar num juízo, uma vez que cabia a ele zelar pelos filhos livres do ventre escravo.

No Juízo dos Órfãos, havia dois tipos de curadores: O Curador Geral de Órfãos e o Curador de Órfãos. O primeiro, que já apresentamos, era aquele que deveria desempenhar a função de Promotor Público no Juízo dos Órfãos e recebia o nome composto de Curador Geral de Órfãos (SOARES, 1906, p. XX); o segundo era um encargo atribuído pelo Juiz de Órfãos a uma pessoa para cuidar de um incapaz (independente da idade), no que dizia respeito à administração de seus bens e/ou recursos. Geralmente, a responsabilidade atribuída ao curador envolvia pessoas maiores de idade que não tinham condições legais ou de saúde, ou eram avaliadas assim, como os indígenas que eram definidos como incapazes pela legislação e deveriam receber curador $^{16}$. Era um cargo transitório que poderia findar com a

13 BRASIL. Reformando o Código do Processo Criminal. Lei no 261 , de 3 de dezembro de 1841. Disponível em <http://www.planalto.gov.br/ccivil 03/leis/LIM/LIM261.htm>. Acesso em: 01/04/2017.

14 BRASIL. Reformando o Código do Processo Criminal, art. 23.

15BRASIL. Lei no 2.048 de 28 de setembro de 1871. Disponível em: <http://www.planalto.gov.br/ccivil 03/Leis/LIM/LIM2040.htm>. Acesso em: 01/04/2017.

${ }^{16}$ Segundo o dicionário Moraes Silva, curador era "O homem que tem cuidado, e administração dos bens do menor, do furioso, pródigo, mudo, etc., em virtude da Lei, ou mando do magistrado". SILVA, Antonio de Moraes. Diccionario da Lingua Portuguesa. Tomo 1. Rio de Janeiro, Oficinas da S. A. 


\section{Revista Brasileira de História \& Ciências Sociais - RBHCS}

Vol. $9 \mathrm{~N}^{\mathrm{O}}$ 18, Julho - Dezembro de 2017

remoção da função por parte do Juiz de Órfãos, ou por seu pedido de exoneração ou ainda a partir da emancipação do curatelado, em caso de se tratar de um menor.

O Curador Geral de Órfãos é, segundo a definição de Oscar de Macedo Soares, ex-Promotor Público,

o funcionário do Ministério Público legalmente nomeado para defender todos aqueles que são inábeis para estar em Juízo e em nome deles falar e requerer, promovendo os seus direitos e evitando assim os danos que resultar-lhes-iam em caso de abandono (SOARES, 1906, cap. II, p. 4).

Sendo assim, o Curador Geral foi a pessoa constituída por lei para representar os interesses dos órfãos e incapazes no Juízo dos Órfãos. Seu papel era muito importante para o andamento das ações, uma vez que, por lei, ele era obrigado a dar "Vistas" em todos os processos, caso contrário, a decisão sobre o caso não teria validade. Em termos práticos, a função era uma atividade mais burocrática, pois sua opinião, quando solicitada, não suplantava a decisão do Juiz de Órfãos. Sua função, pela leitura dos processos de tutela, era a de auxiliar do Juiz para que este não cometesse nenhuma incúria, sem que lhe fosse facultado decidir ou alterar uma sentença. Mesmo assim, era considerado o “Advogado dos Órfãos” por pleitear os interesses dos órfãos e incapazes nos processos que corriam pelo Judiciário.

É importante verificar que, dentro da estrutura do Judiciário, o cargo de Promotor Público era uma das chaves que poderiam abrir portas para a vida política. Segundo Gunter Axt, os

jovens iniciantes com influência política na Corte do Rio de Janeiro tinham maiores chances de conseguir uma nomeação para uma comarca rica ou eleitoralmente promissora. As mudanças de gabinetes e ministérios eram oportunidades para transferências e promoções, pois os novos detentores do poder ambicionavam garantir resultados eleitorais favoráveis, sendo delegados, subdelegados e promotores cargos estratégicos para esse fim (AXT, 2001, p. 53).

Mesmo que não alcançassem êxito numa eleição, estes poderiam, segundo o Regulamento $\mathrm{n}^{0} 120$ de $1825^{17}$, após quatro anos de desempenho como Promotor

Litho-Litotipographia Fluminense, 1922, p. 504. (Edição fac-símile da $2^{\mathrm{a}}$ edição, de 1813 , sendo a $1^{\mathrm{a}}$ edição de Lisboa, Officina de Simão Thadeo Ferreira, em 1789).

17 BRASIL. Regula a execução da parte policial e criminal da Lei no 261 de 3 de Dezembro de 1841. Regulamento $\mathrm{n}^{0} 120$ de 31 de janeiro de 1842. Disponível em: $<$ http://www.planalto.gov.br/ccivil 03/Regulamentos/R120.htm>. Acesso em: 01/o6/2017. 


\section{Revista Brasileira de História \& Ciências Sociais - RBHCS}

Vol. $9 \mathrm{~N}^{\circ}$ 18, Julho - Dezembro de 2017

Público, concorrer ao cargo de Juiz de Direito ou conseguir outra função mais preeminente na magistratura ou política, uma vez que “... parcela considerável dos juízes de direito, desembargadores, presidentes de província, enfim, começara sua carreira política a partir de uma nomeação para uma promotoria" (AXT, 2001, p. 53).

Após a Proclamação da República, em 1889, as antigas províncias - a partir de então, Estados - tinham autonomia em relação ao governo federal para organizar seu Sistema Judiciário, estabelecendo leis que o norteariam. O Rio Grande do Sul não foi diferente, uma vez que o então Presidente do Estado, Júlio Prates de Castilhos, promulgou a Lei $\mathrm{n}^{0}$ 10, de 16 de dezembro de 1895 (RIO GRANDE DO SUL, 1903), que organizava o Judiciário, colocando-o como subordinado à Secretaria do Interior e Justiça. Nessa lei, foi definido o papel do Ministério Público, que teria por propósito: “... representar e defender os interesses do Estado, os da justiça, os de menores, interditos e ausentes e os daqueles a quem a lei conceder o benefício da assistência jurídica” (art. 92).

Com a nova normativa, os Curadores Gerais de Órfãos seriam nomeados, por indicação do Procurador-Geral, pelo presidente do Estado (art. 95). Eles tinham por responsabilidade denunciar e intervir no cuidado de um menor de idade, atuando em situações que envolviam desde maus-tratos, até mesmo a falta de oferta de educação adequada às posses da criança ou do responsável por ela. Além desse zelo, deveriam participar de acordos pré-nupciais de um menor ou mesmo investigar a situação de algum tutelado ou menor desamparado.

Com base nessa lei, a República traria para os Curadores Gerais de Órfãos assim como para todos os Promotores Públicos - a mudança mais significativa: a estabilidade do cargo. Não poderiam ser destituídos do cargo ad nutum, a partir de então, somente por "pedido ou por sentença judicial" (art. 95 §1). Ou seja, estes ganhavam autonomia, já que não necessitavam mais ter sua conduta ou desígnios determinados pelo alinhamento com o poder central, caso contrário, poderiam ser destituídos da função. Assim, os Promotores Públicos possuíam autonomia para expressar seu livre pensar sobre os casos que eram levados para as instituições sem o receio de ir contra o monarca ou o Presidente da Província, como fora no período imperial.

Outra figura de suma importância no Juízo dos Órfãos era o Escrivão, pois este mesmo tinha em suas mãos a responsabilidade de redigir tudo (de forma fiel) que fosse da alçada da instituição (Ord. Fil. liv. $1^{\circ}$, tit. 24, §3 e 16, tit. 19 §11): desde 


\section{Revista Brasileira de História \& Ciências Sociais - RBHCS}

Vol. $9 \mathrm{~N}^{\mathrm{O}}$ 18, Julho - Dezembro de 2017

processos de tutela a exames de sanidade ou de inventários até registros de entradas e saídas do Cofre dos Órfãos ficavam sob sua competência uma vez que tinha fé pública (RIO GRANDE DO SUL, 1903, art. 117).

Ter a seu cargo a redação dos processos também significava ter aumento de ganho, uma vez que o salário dos escrivães estava atrelado a essa tarefa: quanto maior o número de autos em que atuassem, maiores seriam seus ganhos, como ocorreu com o Escrivão Oliveira Bello que somente em um único processo de tutela ${ }^{18}$, arrecadou o valor, nada desprezível, para apenas uma única atuação, de 27\$200 réis ${ }^{19}$. Esses processos, ainda, deveriam ser guardados por 30 anos, a partir da sentença em bom estado de conservação, caso fosse constatado descaso ou deterioração do auto judicial por sua causa, ele seria penalizado com multa (Ord. Fil. liv. $1^{\circ}$, tit. $\left.84 \S 23\right)$.

O Escrivão poderia ter um ajudante, nomeado pelo Juiz de Órfãos, e este tinha autorização para escrever em todos os feitos, menos naqueles em que o Juiz de Órfãos estivesse presente; caso redigisse, o escrivão teria que subassinar para ratificar que aquilo era verdadeiro, uma vez que somente o escrivão, e não seu ajudante, tinha fé pública.

Não obstante, sua presença era obrigatória em duas ocasiões: em todas as audiências do Juízo dos Órfãos (Ord. Fil. liv. $1^{\circ}$, tit. 79 §5) e na abertura do Cofre dos Órfãos, já que deveria entregar recibos e fazer os balancetes deste. Além disso, assim como o Curador Geral de Órfãos, este deveria ter atenção sobre o procedimento dos tutores e notificar o Juiz de Órfão caso verificasse algum ato irregular e ter igual atenção, de forma geral, sobre todos os menores de idade que estavam sob jurisdição da instituição.

Ao Escrivão estava vetada a utilização de trabalho de um menor ou mesmo a apropriação de algum bem deste (Ord. Fil. liv. $1^{\circ}$, tit. 88, §30; tit. 89 §8), assim como atrasar o andamento do processo ou de seu julgamento, por qualquer motivo, mesmo que este fosse o não pagamento das custas (Ord. Fil. liv. $1^{\circ}$, tit. 24 §41, tit. $79 \S 18$, tit. 84 §3).

\footnotetext{
18 RIO GRANDE DO SUL. Juízo Districtal da Vara de Orphãos de Porto Alegre. $1^{\text {a }}$ Vara. Autos de tutoria. Proc. $\mathrm{n}^{0} 2646$ de 1878. [manuscrito]. Porto Alegre, 1878. Localização: APERS.

19 À guisa de ilustração, no Rio de Janeiro da segunda metade do século XIX, um trabalhador urbano necessitaria de pelo menos $19 \$ 000$ (dezenove mil-réis) mensais para custeios com aluguel e alimentação, conforme o estudo de André Dutra Boucinhas intitulado Consumo e comportamento no Rio de Janeiro na segunda metade do século XIX. Dissertação (Mestrado em História), Universidade Federal Fluminense, Niterói,2005.
} 


\section{Revista Brasileira de História \& Ciências Sociais - RBHCS}

Vol. $9 \mathrm{~N}^{\circ} 18$, Julho - Dezembro de 2017

O último "auxiliar" do Juiz dos Órfãos era o Tesoureiro dos Órfãos, indivíduo nomeado pelo Juiz com a finalidade de se fazer presente na abertura do Cofre dos Órfãos, onde eram depositados os valores pertencentes aos menores de idade ou à hipoteca legal ${ }^{20}$ que os tutores deveriam realizar para receber a guarda do menor que possuísse recursos ou bens, além de fazer balanço das entradas e saídas do Cofre dos Órfãos toda vez que o Juiz assim o solicitasse (geralmente no mês de novembro), quando mudasse o Juiz ou mesmo quando terminasse seu trabalho na instituição. A abertura desses livros era semelhante:

Este L. $4^{\circ}$ há de servir para as entradas dos dinheiros do Cofre dos Órfãos pertencentes ao $1^{\circ}$ Cartório por se acharem os que sirvam entregues a uma comissão encarregada de examinarem a falta que se encontra num dos pertences [sic] aos ditos órfãos, vai por mim rubricada com a rubrica que uso $=$ Camara $=$ e por mim igualmente assinado ${ }^{21}$.

O Juízo dos Órfãos poderia ter mais de um Cofre dos Órfãos, uma vez que o valor depositado era muito grande. Analisando os Livros de Entradas ${ }^{22}$ do período de 1850 a $1870^{23}$, ficamos impressionados com o valor de 1.291:114\$778 (hum mil, duzentos e noventa e um contos, cento e quatorze mil e setecentos e setenta e oito réis) recebidos no Cofre dos Órfãos, montante substancial para uma instituição não bancária no período. Ainda sobre o funcionamento do Cofre, é expressivo verificar que, a cada troca de Juiz ou de Tesoureiro, era realizado o balanço dos valores no Cofre, como segue:

Auto de balanço e entrega das chaves dos Cofres dos Órfãos e os dinheiros que faz o Juiz de Órfãos Suplente o cidadão Marcos Alves Pereira Salgado, e seu Tesoureiro Eduardo de Azevedo e Souza, ao

\footnotetext{
${ }^{20}$ Depósito feito pelo tutor como garantia de que, caso viesse a trazer prejuízo econômico ao menor, o órfão não seria lesado, pois, se comprovado, poderia retirar o valor da hipoteca para si. Dispensado para aqueles que fossem tutores de crianças que não possuíssem bens, segundo as Ordenações Filipinas.

${ }_{21}$ Registro de órfãos. Livro de Entrada dos dinheiros dos órfãos. [Manuscrito] Fundo Câmara/Conselho Municipal. Ano 1764-1937. Código: 1.5.3 a 1.5.4. [Manuscrito]. Localização: Arquivo Histórico de Porto Alegre Moysés Vellinho (AHPAMV).

${ }^{22}$ Livro de Entradas. Fundo Câmara/Conselho Municipal. Ano 1764-1937. Código: 1.5.3 a 1.5.4. [Manuscrito]. Localização: Arquivo Histórico de Porto Alegre Moysés Vellinho (AHPAMV).

${ }_{23}$ Nesse intervalo, não foram localizados os livros com os registros para os anos de 1857 a 1860, o que, com certeza, poderia elevar ainda mais o montante recebido no Cofre dos Órfãos do Juízo dos Órfãos de Porto Alegre.
} 


\section{Revista Brasileira de História \& Ciências Sociais - RBHCS}

Vol. $9 \mathrm{~N}^{\mathrm{O}}$ 18, Julho - Dezembro de 2017

Atual Juiz de Órfãos Suplente Joaquim Lopes de Barros, [e] ao novo Tesoureiro Vicente José de Carvalho ${ }^{24}$.

O Juízo dos Órfãos era extremante zeloso para com os bens dos menores, pois, além de cuidar da manutenção dos livros para entradas e saídas de dinheiro do Cofre dos Órfãos, emissão de recibos etc., a instituição estava sempre preocupada com a idoneidade na administração dos recursos. Assim, o Cofre possuía três chaves de abertura que estavam em posse do Juiz, do Tesoureiro e do Escrivão e, somente juntos, estes poderiam abrir o Cofre e movimentar os valores, a fim de evitar o crime de peculato 25 .

Para finalizar, como não era um cargo normatizado no Judiciário, o Tesoureiro dos Órfãos poderia pedir demissão a qualquer momento, desde que fizesse o balancete dos valores presentes no Cofre. Seu salário corresponderia a 1/8 da taxa dos valores recolhidos no Cofre dos Órfãos, que, no caso da cidade de Porto Alegre, renderia uma ótima remuneração.

Dentro da estrutura do Juízo dos Órfãos, havia ainda o Porteiro do Auditório, que, além de abri-lo, deveria manter a ordem no local, fazendo as vezes de segurança.

\section{A formação de uma classe: os bacharéis em direito.}

Ao mesmo tempo em que o Estado português e, após a independência, o brasileiro, reforçavam a necessidade da existência do Juiz de Órfãos, esses criaram mecanismos para a aplicabilidade do corpo de leis nos núcleos familiares e, por conseguinte, na vida privada das famílias, reforçando concepções dos grupos dirigentes nas ações judiciais que eram levadas aos Juízes de Órfãos. Se, num primeiro momento, as ações dessa instituição estavam relacionadas a assuntos financeiros (como o zelo por aqueles menores que deveriam receber uma herança), ao longo do tempo, passaram a ser direcionadas para temas sociais. Talvez, por ser o juiz o que mais se aproximasse dos assuntos de cunho privado/familiar, o Estado

24 Registro de órfãos. Livro de Entrada dos dinheiros dos órfãos. [Manuscrito] Fundo Câmara/Conselho Municipal. Ano 1764-1937. Código: 1.5.3 a 1.5.4. [Manuscrito]. f.30. Localização: Arquivo Histórico de Porto Alegre Moysés Vellinho (AHPAMV).

${ }_{25}$ "Crime de apropriação de dinheiro, rendimentos públicos ou de outro bem móvel qualquer, por funcionário público...”. SANTOS, Washington dos. Dicionário jurídico brasileiro. Belo Horizonte/MG: Del Rey, 2001, p. 181. 


\section{Revista Brasileira de História \& Ciências Sociais - RBHCS}

Vol. $9 \mathrm{~N}^{\mathrm{O}}$ 18, Julho - Dezembro de 2017

percebeu as potencialidades que este possuía como seu representante nas localidades, principalmente, na regulação dessas famílias.

Com a subsequente exigência do diploma de bacharel em direito para ocupação do cargo de Juiz de Órfãos, o Estado aspirava formar um grupo de pessoas habilitadas, tanto para instrumentalizar o corpo de leis, como para refletir as diretrizes do campo jurídico (por conseguinte, do próprio Estado) nas interposições sociais.

Os cursos superiores, na América portuguesa, demoraram a surgir, enquanto que, na América espanhola, eles já haviam sido criados em 1538. Essa ausência, que só seria suprida no século XIX, deve-se à formação centralizada que Portugal havia aplicado à sua colônia, formatando costumes desse grupo da elite colonial, que cruzava o Atlântico para estudar na Europa, em especial, na Metrópole e, principalmente, na Universidade de Coimbra.

O cenário brasileiro mudaria com a vinda da família real para os trópicos, em 1808. A partir de então, houve alguns avanços importantes na educação de ensino superior, como a fundação da Faculdade de Medicina, no Rio de Janeiro e na Bahia. No entanto, não fazia parte das preocupações imediatas do Estado a formação local de pessoas habilitadas para exercerem atividades na administração estatal, na qual se incluíam os bacharéis em Direito.

A formação de juristas não era urgente. A Universidade de Coimbra forneceu-nos bacharéis em Direito em número suficiente [...]. A relação de nossos estadistas, magistrados e professores é toda de bacharéis de Coimbra. Todo o Brasil político e intelectual foi formado em Coimbra, único centro formador do mundo português. Era um ponto básico da orientação da Metrópole essa formação centralizada. (LACOMBE, 1985, p. 361).

Devido à necessidade de viajar para obter o diploma de bacharel e, consequentemente, de arcar com os custos do curso, alimentação e estadia em Portugal, pouquíssimos foram aqueles afortunados que empreenderam a prestigiosa tarefa de estudar em Coimbra. Dessa forma, podemos elencar dois fatores predominantes para a pouca disseminação do Direito em solo brasileiro antes da constituição de quadros formados nas Faculdades de Direito de São Paulo e Olinda/Recife: primeiramente, o Direito representava uma forma de dominação dos ideais metropolitanos no Brasil, sem que o mesmo tivesse a possibilidade de criar ou gerenciar seu próprio sistema jurídico e, segundo, a superficialidade com que a 


\section{Revista Brasileira de História \& Ciências Sociais - RBHCS}

Vol. $9 \mathrm{~N}^{\mathrm{O}}$ 18, Julho - Dezembro de 2017

cultura jurídica era analisada, uma vez que a maior parte da população era analfabeta e o processo civilizador ainda não estava em marcha (VENANCIO FILHO, 2011).

Sendo assim, somente em 1827, já no Brasil independente e, em vista da necessidade de formação de um Estado nacional brasileiro, é que há o empenho na criação de cursos jurídicos no lado de cá do Atlântico, respectivamente, em Olinda/Pernambuco e em São Paulo. Embora o corpo docente tivesse sido formado nos bancos escolares de Coimbra, as aulas foram iniciadas já no ano seguinte (1828), o que representou a gênese da formação de uma cultura jurídica e ideológica brasileira.

Os cursos jurídicos no Brasil imperial constituíam o manancial daqueles que percorreriam carreiras jurídicas e políticas, formando, sobretudo, a elite política que conduziria o Brasil por longo período (CARVALHO, 2010). Segundo Gilberto Amado,

o bacharelismo foi o primeiro capítulo da burocracia. Dele é que nasceu esta irresistível inclinação ao emprego público que o novo regime não pôde conjurar, antes acoroçoou, porque, não tendo criado o trabalho nem a instrução profissional, não pôde evitar que se dirigissem para os cargos públicos os moços formados na academia, inaptos à lavoura, ao comércio, aos ofícios técnicos (Apud VENANCIO FILHO, 2011, p. 286, destaque no original).

Esse grupo de bacharéis que se formava exigia cada vez mais uma intervenção do Estado na oferta de trabalho para sua classe, e um dos cargos que era almejado pelos egressos (e também pelas lideranças locais), desde o tempo da colônia, era o de Juiz de Órfãos ou mesmo o de Curador Geral de Órfãos (CARDOZO, 2015).

Assim, com a formação de um novo pensamento jurídico baseado nos pressupostos nacionais, alguns pontos legais do Estado nacional brasileiro, no Império e, até mesmo no início do século XX, já no período republicano, estavam assentados nos princípios legais portugueses. As Ordenações Filipinas, de 1603, em muitos aspectos, manteve sua vigência no período imperial, tendo sido substituída em alguns assuntos ao longo do tempo. Isso ocorreu com o Código Criminal, de 1830, o Código Comercial, de 1850, o Código Civil, de 1917, e, por fim, e para o tema que mais nos interessa, que é o Juízo dos Órfãos, perdura até o ano de 1927, quando entrou em vigor o Código de Menores. 


\section{Revista Brasileira de História \& Ciências Sociais - RBHCS}

Vol. $9 \mathrm{~N}^{\mathrm{O}}$ 18, Julho - Dezembro de 2017

\section{O Juiz de Órfãos e suas prerrogativas}

As Ordenações Filipinas dedicavam dois títulos para o "Juízo dos Órphãos", um no primeiro livro e, outro, no quarto, deixando claro o porquê da sua existência:

Antigamente o prover sobre as pessoas e fazendas dos órfãos pertencia aos juízes ordinários e tabeliães, e por suas ocupações serem muitas, e não poderem cumprir com esta obrigação, como deviam, foram ordenados os ofícios de juiz e escrivão dos órfãos, para especialmente proverem nas pessoas e fazendas deles, no que devem ter grande cuidado, pela muita confiança, que neles é posta. E em todas as vilas e lugares, onde neles e no termo que houver quatrocentos vizinhos, ou daí para cima, mandamos que haja juiz de órfãos apartado. E onde não houver o número de vizinhos, os juízes ordinários sirvam o ofício de juiz de órfãos com os tabeliães da vila [...]. Os quais juízes ordinários serão obrigados a cumprir e guardar em tudo o conteúdo deste título, sob as penas nele declaradas (Ord. Fil. liv.1, tit. 88).

Para que um caso fosse de sua alçada, era necessário que houvesse um órfão (menor de idade) como parte interessada no processo, mas, também, estavam sob sua responsabilidade as seguintes pessoas: "Furiosos", "Mentecaptos", "Pródigos", "Desassisados'6", "Ausentes" e "Surdos/Mudos", todos definidos como "incapazes" (Ord. Fil. liv. 1, tit. 78 e 90 e liv.4, tit. 103). Além desses, no decorrer do século XIX, foram incluídos os indígenas, as mulheres solteiras ou casadas (quando o pai ou o marido estavam ausentes) e os "ingênuos", filhos do ventre escravo, assim como aqueles que tinham pais desconhecidos (incógnitos) e cujas mães não fossem consideradas aptas por não apresentarem (ou representarem) possuir um comportamento "adequado" à vida em sociedade.

Competia ao Juiz de Órfãos:

[...] conhecer e julgar administrativamente os processos de inventários, partilhas, tutelas, curadorias, contas de tutores e curadores. Pertence-lhes, outrossim: $1^{0}$ as cartas de emancipação; $2^{0}$ os suprimentos de idade; $3^{\circ}$ as licenças as mulheres menores para venderem bens de raiz, consentindo os maridos; $4^{\circ}$ dar tutores em todos os casos marcados nas leis; $5^{\circ}$ suprir o consentimento do pai ou tutor para casamento; $6^{\circ}$ a entrega de bens de órfãos às suas mães, avós, tios, etc.; $7^{\circ}$ a entrega de bens de ausentes a seus parentes mais chegados; $8^{\circ}$ a entrega de bens de órfãos a seus maridos, quando

\footnotetext{
26 Pessoa sem siso, sem juízo.
} 


\section{Revista Brasileira de História \& Ciências Sociais - RBHCS}

Vol. $9 \mathrm{~N}^{\mathrm{O}}$ 18, Julho - Dezembro de 2017

casarem sem a licença dos mesmos juízes; $9^{\circ}$ a dispensa para tutores obrigarem seus próprios bens à fiança das tutelas para que foram nomeados, ainda que os bens estejam fora dos distritos onde contraíram a obrigação; $10^{\circ}$ conhecer e julgar contenciosamente as causas que nascem dos inventários, partilhas e contas dos tutores; e bem assim as habilitações dos herdeiros do ausente, e as causas que forem de dependência de todas as que ficam referidas nesse parágrafo; $11^{\mathrm{O}}$ arrecadação e administração dos bens dos ausentes; $12^{\circ}$ a administração dos bens pertencentes aos índios (CARVALHO, 1880, p. 57).

Sendo assim, o Juiz de Órfãos era aquele que, por lei, tinha a responsabilidade sobre todos os órfãos ou menores de idade ou, mesmo, incapazes, ficando todos sob sua alçada. Suas ações eram necessárias quando houvesse a realização de um inventário; quando houvesse separação entre os pais; na nomeação de tutor ou curador para um menor ou incapaz; na fiscalização do procedimento e das despesas do tutor ou curador em relação a seu tutelado ou curatelado.

Além dessas atividades, o Juiz de Órfãos poderia emancipar, por meio de processo de Suplemento de Idade ${ }^{27}$, dar licença para casamento (sem a necessidade da autorização do responsável pelo menor), fazer a análise das contas do Cofre dos Órfãos ${ }^{28}$, nomear os Oficiais de Justiça e o Ajudante do Escrivão.

Contudo, a ele não era permitido advogar ou aconselhar as partes envolvidas no processo (Ord. Fil. liv. $1^{0}$, tit. 6 §22), assim como ser o escrivão seu parente ou mesmo aproveitar-se de um bem ou serviço de algum órfão (Ord. Fil. liv. $1^{\circ}$, tit. 88 §30; liv. $4^{\text {a }}$, tit. 15$)$.

Os Juízes de Órfãos, desde 1731, ano da normatização do cargo no Brasil, até 1824, ano da promulgação da Carta Constitucional, estavam submetidos diretamente ao Corregedor e ao Ouvidor Geral, e estes, ao Tribunal de Relação, que estava subordinado, por fim, à Casa de Relação do Rio de Janeiro, a qual teve o nome alterado para Casa de Suplicação, por ocasião da estadia da família real portuguesa, tendo mudado, mais uma vez, no período do Brasil independente, para Superior Tribunal de Justiça (FÉLIX, 1999).

\footnotetext{
${ }_{27}$ Processo pelo qual o menor, ou o representante legal deste, solicitava a emancipação.

${ }^{28}$ Nome dado à captação dos dinheiros pertencentes aos órfãos, que era confiado a um depositário ou a uma conta bancária na qual eram depositados os valores referentes ao soldo de um menor ou mesmo a hipoteca legal sobre os bens de um menor. Essa hipoteca era necessária como garantia de que o tutor não dilapidaria o capital que porventura o menor possuísse. O dinheiro depositado poderia ser aplicado, ou mesmo poderia ser realizado um empréstimo pelo Estado para, com os rendimentos desta (juros), poder contribuir com a manutenção do menor, quando o Juiz achasse pertinente.
} 


\section{Revista Brasileira de História \& Ciências Sociais - RBHCS}

Vol. $9 \mathrm{~N}^{\mathrm{O}}$ 18, Julho - Dezembro de 2017

A Constituição de 1824 foi um importante passo rumo à autonomia do Estado brasileiro, mas seria o Código do Processo Criminal, de 1832, que daria o suporte da construção da carreira jurídica no país.

Esse código, em pouco tempo, foi reformado, trazendo importante normatização aos Juízes de Órfãos, pois, segundo a Lei no 261, de 3 de Dezembro de 1841 (Reforma do Código do Processo Criminal), no título II, Sobre os Juízes Municipais e Recursos, em seu artigo 117, apresenta que

Estes Juízes serão escolhidos pelo Imperador d'entre os Bacharéis formados, habilitados para serem Juízes Municipais, servirão pelo mesmo tempo que os Juízes Municipais e serão substituídos da mesma maneira. Vencerão o ordenado e emolumentos, e terão a mesma alçada dos Juízes Municipais²9.

José Murilo de Carvalho, esclarece-nos quanto à importância dessa reforma, ao apontar que ela definiria o sistema judiciário que se perpetuaria, com poucas modificações, no Império. Nela,

a magistratura togada abrangia desde juízes municipais até os ministros do Supremo Tribunal de Justiça. Os juízes municipais e de órfãos eram nomeados entre bacharéis com um ano de prática forense para períodos de quatro anos. Podiam então ser promovidos a juiz de direito, ou ser nomeados para outro quadriênio, ou mesmo abandonar a carreira, pois não tinham estabilidade. Já os juízes de direito possuíam estabilidade e só perdiam o cargo por processo legal, embora pudessem ser removidos de um lugar para outro. [...] O grau mais alto da carreira era o Supremo Tribunal de Justiça do Rio de Janeiro, cujos membros tinham honras de ministros (CARVALHO, 2010, p. 174-175).

Esse cenário só se alteraria no ano de 1871, quando ocorreu uma substancial reformulação na lei, com o propósito de delimitar as atividades da polícia e do judiciário, que haviam ficado entrelaçadas em 1841 (CARVALHO, 2010). Como já argumentamos, quando ocorreu a Proclamação da República no Brasil, o sistema jurídico ficou entregue a cada antiga província que, a partir de então, passou a nutrir autonomia para legislar e organizar seu judiciário. Embora houvesse essa autonomia, os recém-instituídos Estados redigiram seu corpo de leis baseados em códigos legais

\footnotetext{
29 BRASIL. Reformando o Código do Processo Criminal. Lei ${ }^{0}$ 261, de 3 de dezembro de 1841. Disponível em <http://www.planalto.gov.br/ccivil 03/leis/LIM/LIM261.htm>. Acesso em: $02 / 06 / 2017$
} 


\section{Revista Brasileira de História \& Ciências Sociais - RBHCS}

Vol. $9 \mathrm{~N}^{\mathrm{O}}$ 18, Julho - Dezembro de 2017

anteriores, e as Ordenações Filipinas representaram um importante fundamento desse novo momento que o Estado brasileiro vivia.

Tendo essa orientação jurídica por base, o Estado do Rio Grande do Sul, como já mencionado anteriormente, organizou seu Judiciário e, consequentemente, as atribuições dos Juízes de Órfãos por meio da Lei no 10 , de 16 de dezembro de 1895 (RIO GRANDE DO SUL, 1903). Nessa normativa ficava determinado que os juízes iriam atuar em distritos (frações dos municípios), que teriam prazo de 30 dias para assumir o cargo, caso contrário, perderiam a nomeação; seriam nomeados pelo presidente do Estado para um mandado de quatro anos, podendo ser reconduzidos e que, finalmente, não perderiam o cargo antes do término do mandato, exceto se incorressem em alguns dos itens do artigo 72 da referida lei, abaixo listados:
a) Por mudança definitiva para fora do distrito;
b) Por aceitação de cargo incompatível;
c) Por impedimento prolongado por mais de seis meses;
d) Por sentença condenatória.

Dessa forma, assim como o Curador Geral, o Juiz de Órfãos passaria a ganhar maior estabilidade e, com isso, pôde expor suas posições sem o receio de facilmente perder o cargo; contudo, ainda poderia haver o temor de não ter a renovação do mandato ou, mesmo, de poder ser penalizado com a não indicação para outra função de maior prestígio, caso fosse avesso a alguma posição do governo. Mesmo assim, a função era por demais prestigiosa e, como temos visto, catapultava o magistrado para posições de destaque dentro da estrutura do judiciário ou mesmo da sociedade de forma geral, como podemos verificar por meio de duas carreiras.

Investigar a história da Justiça Orfanológica e de seus agentes é devolver a dinâmica histórica de nossa sociedade passada e aprofundar a história do Direito e da Justiça brasileira. Assim, este texto buscou apresentar a significativa participação social que o Juízo dos Órfãos teve para o seu tempo e as mudanças que houve na legislação que atribuíram aos operadores do direito maior prestígio e estabilidade no cargo dentro da Justiça Orfanológica, tornado a função desejada para os operadores do direito.

\section{Referências Bibliográficas}


ALMEIDA, Cândido Mendes de. Código Filipino ou Ordenações e leis do Reino de Portugal, recompiladas por mandado do rei D. Philippe I. 14. ed. Rio de Janeiro: Tipografia do Instituto Philomathico, 1870.

AXT, Gunter. O Ministério Público no Rio Grande do Sul: evolução histórica. Porto Alegre: Procuradoria-Geral de Justiça, 2001.

BOUCINHAS, André Dutra. Consumo e comportamento no Rio de Janeiro na segunda metade do século XIX. Dissertação (Mestrado em História), Universidade Federal Fluminense, Niterói, 2005.

BOURDIEU, Pierre. Sobre o Estado: cursos no Collège de France (1989-1992). Tradução Rosa Freire d'Aguiar. São Paulo: Companhia das Letras, 2014.

CARDOZO, José Carlos da Silva. Enredos tutelares: o Juízo dos Órfãos e a atenção à criança e à família porto-alegrense no início do século XX. São Leopoldo/RS: Oikos; Editora UNISINOS, 2013.

CARDOZO, José Carlos da Silva. "Como se fosse meu filho"? As crianças e suas famílias no Juízo dos Órfãos de Porto Alegre (1860-1899). Tese (Doutorado em História). Universidade do Vale do Rio dos Sinos, São Leopoldo, 2015.

CARVALHO, José Murilo de. A construção da ordem: a elite política imperial. Teatro das sombras: a política imperial. 5. ed. Rio de Janeiro: Civilização Brasileira, 2010.

CARVALHO, José Pereira de. Primeiras linhas sobre o processo orphanológico. 9. ed. Rio de Janeiro: Laemmert, 1880.

CHALHOUB, Sidney. Machado de Assis: historiador. São Paulo: Companhia das letras, 2007.

FÉLIX, Loiva Otelo; et al. Tribunal de Justiça do RS: 120 anos de história (18741999). Porto Alegre: Projeto Memória do Judiciário Gaúcho, 1999.

GEBARA, Ademir. O mercado de trabalho livre no Brasil. São Paulo: Editora Brasiliense, 1986.

HESPANHA, António Manuel. História das instituições: épocas medieval e moderna. Coimbra/PT: Livraria Almedina, 1982.

LACOMBE, Américo Jacobina. A cultura jurídica. In: HOLANDA, Sérgio Buarque de. História da civilização brasileira. São Paulo, SP: Difel, 1985.

LARA, Silvia (Org.). Ordenações Filipinas: Livro V. São Paulo: Companhia das Letras, 1999.

MACHADO, Maria de Fátima. Os órfãos e os enjeitados da cidade e do termo do Porto (1500-1580). Tese (Doutorado em História). Universidade do Porto, Porto/PT, 2010.

MARCOS, Rui de Figueiredo; MATHIAS, Carlos Fernando; NORONHA, Ibsen. História do direito brasileiro. Rio de Janeiro: Forense, 2014.

MOREIRA, Paulo Roberto Staudt. Entre o deboche e a rapina: os cenários sociais da criminalidade popular em Porto Alegre. Porto Alegre: Armazém Digital, 2009.

RIO GRANDE DO SUL. Lei n. 10 de 16 de dezembro de 1895: organização judiciária. Porto Alegre: Officinas Typographicas de Echenique Irmãos, 1903. 
RIO GRANDE DO SUL. Ministério Público. Centro de Apoio Operacional de Infância e da Juventude. Estatuto da criança e do adolescente e legislação pertinente. Porto Alegre: Procuradoria-Geral de Justiça, 2007.

SANTOS, Washington dos. Dicionário jurídico brasileiro. Belo Horizonte/MG: Del Rey, 2001.

SILVA, Antonio de Moraes. Diccionario da Lingua Portuguesa. Tomo 1. Rio de Janeiro, Oficinas da S. A. Litho-Litotipographia Fluminense, 1922, p. 504. (Edição fac-símile da $2^{\mathrm{a}}$ edição, de 1813 , sendo a $1^{\mathrm{a}}$ edição de Lisboa, Officina de Simão Thadeo Ferreira, em 1789).

SOARES, Oscar de Macedo. Manual do curador geral dos orphãos, ou, Consolidação de todas as leis, decretos, regulamentos, avisos e mais disposições de processo relativas áquelles funccionarios. 2. ed. rev. Rio de Janeiro: H. Garnier, 1906, p. XX.

VENANCIO FILHO, Alberto. Das arcadas ao bacharelismo: 150 anos de ensino jurídico no Brasil. 2. ed. São Paulo: Perspectiva, 2011.

Recebido em Agosto de 2017 Aprovado em Outubro de 2017

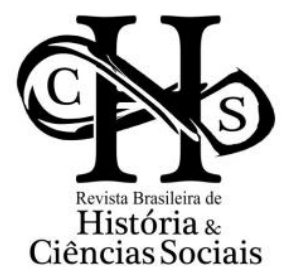

